\title{
Search for Highly Conserved Viral and Bacterial Nucleic Acid Sequences Corresponding to an Etiologic Agent of Kawasaki Disease
}

\author{
ANNE H. ROWLEY, STEVEN M. WOLINSKY, DAVID A. RELMAN, SUSAN P. \\ SAMBOL, JANET SULLIVAN, MASARU TERAI, AND STANFORD T. SHULMAN \\ Departments of Pediatrics [A.H.R., S.P.S., S.T.S.] and Medicine [S.M.W.], Northwestern \\ University, Chicago, Illinois 60611 [S.M.W.], and the Children's Memorial Hospital, Chicago, \\ Illinois 60614 [A.H.R., S.P.S., S.T.S.]; Departments of Medicine, Microbiology, and \\ Immunology, Stanford University School of Medicine, Stanford, California 94305 [D.A.R.]; Palo \\ Alto Department of Veterans Affairs Medical Center, Palo Alto, California 94304 [D.A.R., J.S.]; \\ and Department of Pediatrics, Chiba University School of Medicine, Chiba, Japan [M.T.]
}

\section{ABSTRACT}

The use of conventional methods to detect a possible infectious cause of Kawasaki disease (KD) has been unsuccessful. Using the polymerase chain reaction and DNA hybridization techniques, we have sought evidence that a known or new herpesvirus, parvovirus, or bacterial pathogen is related etiologically to $\mathrm{KD}$. Peripheral blood DNA from acute $\mathrm{KD}$ patients was subjected to amplification and dot-blot hybridization to detect the presence of herpesvirus DNA, and acute $\mathrm{KD}$ peripheral blood and serum DNA were subjected to dot-blot hybridization for the presence of parvoviral DNA. All samples were negative for both herpesvirus and parvovirus DNA. In addition, we analyzed buffy-coat white blood cell DNA, synovial fluid DNA, and frozen autopsy and formalin-fixed, paraffin-embedded myocardial tissue DNA from $\mathrm{KD}$ patients for the presence of highly conserved bacterial $16 \mathrm{~S}$ ribosomal RNA gene sequences with the polymerase chain reaction, and all were negative. These results argue against a direct pathogenic role for herpesviruses, parvoviruses, and bacteria in $\mathrm{KD}$. This approach to the detection of highly conserved genomic sequences among broad groups of microorganisms can be adapted for the detection of other groups of microorganisms and may yet prove useful in the search for an etiologic agent of KD. (Pediatr Res 36: 567-571, 1994)
KD, Kawasaki disease
Abbreviations
PCR, polymerase chain reaction
rRNA, ribosomal RNA
rDNA, ribosomal DNA
CMV, cytomegalovirus
Taq, Thermus aquaticus

The etiology of $\mathrm{KD}$ remains unknown. Both clinical and epidemiologic features strongly suggest an infectious etiology (1). The herpesvirus and parvovirus families include agents that cause human diseases, particularly in children, and that bear clinical similarities to $\mathrm{KD}$. These include parvovirus B19, the causative agent of erythema infectiosum (fifth disease), which results in fever, rash, conjunctivitis, pharyngitis, and arthralgia in childhood, and human herpesvirus type 6 , the causative agent of exanthem subitum (roseola), which results in fever and

Received February 1, 1994; accepted May 20, 1994.

Correspondence: Anne H. Rowley, M.D., Department of Pediatrics, Section of Infectious Diseases, Loyola University Medical Center, 2160 South First Avenue, ET Bldg., Maywood, IL 60153.

Supported by the Bayer Fund for Cardiovascular Research (A.H.R.), the Kawasaki Disease Research Fund of the Children's Memorial Hospital (A.H.R., S.T.S.), the Wenger Senior Fellowship of the American Heart Association (A.H.R.), the Lucille P. Markey Charitable Trust (D.A.R.), and the SmithKline Beecham/PMGM Director's Research fund (D.A.R., J.S.). rash in young children. Several animal parvoviruses induce illnesses characterized by immune-mediated vasculitis, such as Aleutian disease virus of mink, or by myocarditis, such as feline parvovirus (2). There is no consistent serologic response to any known human herpesvirus or parvovirus in $\mathrm{KD}$ patients, but the possibility exists that a previously unknown herpesvirus or parvovirus may be etiologically related to $\mathrm{KD}$.

Recent advances in nucleic acid amplification technology and the discovery of $16 \mathrm{~S}$ rRNA sequences common to all known members of the bacterial domain have made possible the identification of previously uncharacterized and uncultured bacterial pathogens directly from infected tissue $(2,3)$. A recent study suggesting that a superantigen may play a role in the pathogenesis of $\mathrm{KD}(4)$ has renewed interest in a possible bacterial cause of the illness.

The purpose of this study was to determine whether highly conserved nucleic acid sequences from the human 
herpesviruses or the human or animal parvoviruses are present in peripheral blood of patients with acute KD. Additionally, we sought to determine whether bacterial rRNA sequences were present in a variety of tissues from $\mathrm{KD}$ patients. Such a finding would suggest that a known or new herpesvirus, parvovirus, or bacterium may be etiologically linked to this illness.

\section{METHODS}

Patients and specimens. Peripheral blood $(6 \mathrm{~mL}$; mean white blood cell count $\left.=15000 / \mathrm{mm}^{3}\right)$, serum, or buffycoat cell preparations (mean $5 \times 10^{6}$ cells per preparation) were obtained from patients who met the accepted diagnostic criteria for $K D(1)$ and who presented within the first $10 \mathrm{~d}$ of illness. Samples were obtained before the administration of i.v. gamma globulin and aspirin therapy. Frozen heart tissue from the autopsy of an infant who died on d 18 of $\mathrm{KD}$ (5) was obtained. Formalin-fixed, paraffinembedded coronary artery and myocardial tissues were obtained from a $\mathrm{KD}$ patient at the time of heart transplantation $12 \mathrm{wk}$ after the onset of the illness (6). Formalinfixed, paraffin-embedded myocardial tissue was also obtained from a patient who died suddenly $3 \mathrm{wk}$ after the onset of $\mathrm{KD}$; lymphocytic myocardial infiltration was present in this tissue. Non-KD control samples included formalin-fixed, paraffin-embedded lymph node with reactive hyperplasia from an adult with no evidence of a KD-like illness. Positive control samples included digested Bordatella pertussis and Escherichia coli cells (for bacterial 16S rRNA primers), K562 human lymphoid cell chromosomal DNA (for $\beta$-globin primers), human lymphocyte DNA (for HLA primers), recombinant pKOS BamHI fragment DNA of herpes simplex virus type 1 , which includes the DNA polymerase gene of herpes simplex virus type 1 (graciously provided by Dr. Donald Coen, Boston, MA), lymphocytes extracted from a patient with CMV viremia (graciously provided by Dr. Jan Andersson, Stockholm, Sweden), and recombinant plasmids of adeno-associated virus, bovine parvovirus, human parvovirus B19, and minute virus of mice (graciously provided by Dr. Peter Tattersall, New Haven, CT). Synovial fluid was obtained from a hip aspirate from an acute $\mathrm{KD}$ patient with clinical signs of arthritis in the joint.

Detection of human herpesviruses. We have developed PCR primers from the two most highly conserved regions among the DNA polymerase genes of the human herpesviruses (7). PCR product resulting from the use of these primers is then detected by hybridization with a degenerate generic human herpesvirus probe that is derived from a highly conserved region within the amplified segment. We have shown that all the known human herpesviruses can be detected by this method, with the exception of human herpesvirus type 7 , which has not been tested (7). With this method, as few as 27 copies, or $2 \times$ $10^{-4} \mathrm{pg}$, of CMV plasmid DNA can be detected (7) using a specific CMV probe within the amplified fragment.
To perform the human herpesvirus PCR, DNA was extracted from 1-3 $\mathrm{mL}$ of heparinized or EDTAperipheral blood from $14 \mathrm{KD}$ patients by incubation in lysis buffer $[50 \mathrm{mM} \mathrm{KCl}, 10 \mathrm{mM}$ Tris- $\mathrm{HCl}$ (pH 8.3), 2.5 $\mathrm{mM} \mathrm{MgCl} 2,0.45 \%$ Nonidet P-40, $0.45 \%$ Tween 20$]$ with proteinase $\mathrm{K}(60 \mu \mathrm{g} / \mathrm{mL})$ at $55^{\circ} \mathrm{C}$ for $1 \mathrm{~h}$ and $95^{\circ} \mathrm{C}$ for 10 min, followed by phenol-chloroform extraction and ethanol precipitation. DNA was amplified in a $100-\mu \mathrm{L}$ reaction containing $50 \mathrm{mM} \mathrm{KCl} ; 10 \mathrm{mM}$ Tris- $\mathrm{HCl}(\mathrm{pH} \mathrm{8.3)}$; $2.5 \mathrm{mM} \mathrm{MgCl}$; gelatin $1 \mathrm{mg} / \mathrm{mL} ; 200 \mu \mathrm{M}$ each deoxyadenosine triphosphate, deoxycytosine triphosphate, deoxyguanosine triphosphate, and deoxythymidine triphoshate; 2 units of Taq DNA polymerase; and 50 pmol of each oligonucleotide primer, AR1, 2, 3, and 4, in one reaction. Primer sequences are as follows $\left(5^{\prime}\right.$ to $\left.3^{\prime}\right)$ : AR1 GACTTTGCCAGCCT, AR2 GATTTTGCAACTTT, AR3 GTCCGTGTCCCCGTA, AR4 ATCCGTATCTCCATA. The size of the amplified products are in the range of 480-580 bp depending on the specific herpesvirus. AR1 and AAR3 are located at nucleotide positions 2151-2163 and 2724-2736, respectively, of the CMV DNA polymerase gene. Samples that demonstrated an amplified product of the expected size (268 bp for $\beta$-globin, $242 \mathrm{bp}$ for HLA primers) on an ethidium bromide-stained $1 \%$ agarose gel, confirming that the sample DNA was of sufficient quality to be amplified (8), were tested with the herpesvirus primers. Amplifications were performed in an automated DNA Thermal Cycler (Perkin Elmer Cetus, Norwalk, CT) for two cycles of low-stringency annealing, with thermal denaturation at $94^{\circ} \mathrm{C}$, primer annealing at $37^{\circ} \mathrm{C}$, and Taq-polymerase-directed primer extension at $72^{\circ} \mathrm{C}$, followed by 35 cycles of higher-stringency primer annealing at $55^{\circ} \mathrm{C}$. HLA amplifications were performed with 35 cycles of higher-stringency annealing only.

Herpesvirus-amplified product was subjected to dotblot hybridization with a degenerate human herpesvirus probe, AR13: 5' to $3^{\prime} \mathrm{TG}(\mathrm{T}, \mathrm{C}) \mathrm{AA}(\mathrm{C}, \mathrm{T})(\mathrm{T}, \mathrm{G}) \mathrm{C}(\mathrm{G}, \mathrm{T}, \mathrm{C})$ $(\mathrm{G}, \mathrm{T}) \mathrm{T}(\mathrm{G}, \mathrm{C}) \mathrm{TACGG}(\mathrm{G}, \mathrm{C}, \mathrm{T}) \mathrm{TT}(\mathrm{C}, \mathrm{T}) \mathrm{AC}(\mathrm{G}, \mathrm{C}, \mathrm{T}) \mathrm{GG}$ $(A, G, C) G T(G, T)(C, G)$ (parentheses indicate degenerate base positions). A one-tenth volume aliquot of amplified product was subjected to alkaline denaturation $(0.4 \mathrm{M}$ $\mathrm{NaOH}, 25 \mathrm{mM}$ EDTA) and spotted onto a nylon membrane. After UV transillumination for $5 \mathrm{~min}$, the membrane was prehybridized at $68^{\circ} \mathrm{C}$ for $45 \mathrm{~min}$ in $2 \times \mathrm{SSC}$ $(20 \times \mathrm{SSC}=3 \mathrm{M} \mathrm{NaCl}, 0.3 \mathrm{M} \mathrm{Na}$ citrate, $\mathrm{pH} 7.0), 10 \times$ Denhardt's, $0.5 \% \mathrm{SDS}$, and then hybridized at $55^{\circ} \mathrm{C}$ for 3 $\mathrm{h}$ in the prehybridization solution to which was added herring sperm DNA $(0.1 \mathrm{mg} / \mathrm{mL})$ and polynucleotide kinase ${ }^{32} \mathrm{P}$-labeled AR-13 probe $\left(1 \times 10^{6} \mathrm{cpm} / \mathrm{mL}\right)$. After washing the membrane twice in $2 \times \mathrm{SSC}, 0.1 \% \mathrm{SDS}$ for 10 min at room temperature, autoradiography was performed using Kodak XAR film with an intensifying screen at $-70^{\circ} \mathrm{C}$ for $16 \mathrm{~h}$.

Detection of human and animal parvoviruses. The human and animal parvoviruses contain a highly conserved DNA sequence in the region coding for nonstructural proteins. We developed a degenerate nucleic acid oligonucleotide probe from this region that detects parvovi- 
ruses that are otherwise quite diverse genetically. This probe is an adaptation of a previously described "universal parvovirus probe" (9).

DNA was extracted from whole blood of $14 \mathrm{KD}$ patients and processed for dot-blot hybridization as for herpesvirus detection. In addition, $20 \mu \mathrm{L}$ of acute $\mathrm{KD}$ serum from $15 \mathrm{KD}$ patients was treated with proteinase $\mathrm{K}$, denatured with alkali, and subjected to dot-blot hybridization. Each membrane was hybridized with $3 \times 10^{6}$ $\mathrm{cpm} / \mathrm{mL}$ of polynucleotide kinase ${ }^{32} \mathrm{P}$-labeled parvovirus probe PV-3 [5' to 3': AC(T,G)TTTCCA(C,T)TTT(C)A$\mathrm{AT}(\mathrm{C}) \mathrm{GA}$ ] for $3 \mathrm{~h}$ at $42^{\circ} \mathrm{C}$ and washed, and autoradiography was performed as above. This probe sequence represents nucleotide position $1505-1520$ of human parvovirus B19.

Detection of bacterial 16S rDNA. Buffy-coat white blood cells were isolated by standard techniques from eight patients with acute $\mathrm{KD}$; a mean of $5 \times 10^{6}$ cells per patient were tested. DNA was extracted from these cells as above, as well as from synovial fluid cells $(0.5 \mathrm{~mL}$; cell count: white blood cells $=28100 / \mathrm{mm}^{3}, 92 \%$ polymorphonuclear cells, $8 \%$ mononuclear cells; red blood cells $=7630 / \mathrm{mm}^{3}$ ) from one patient with acute $\mathrm{KD}$ and from frozen myocardial tissue from a patient who died on $\mathrm{d} 18$ of illness (5). For the latter tissue, RNA was first extracted from the tissue using a standard guanidium thiocyanate-acid phenol method (10), and the DNA was back-extracted using alkaline ( $\mathrm{pH}$ 8.0) phenol. The DNA samples were subjected to 25 cycles of PCR amplification using primers derived from highly conserved regions of bacterial 16S rRNA genes (p93E and p13B) as described by Relman et al. (2) using the same methods as outlined for human herpesvirus PCR, with thermal denaturation at $95^{\circ} \mathrm{C}$, primer annealing at $55^{\circ} \mathrm{C}$, and Taq polymerasemediated primer extension at $72^{\circ} \mathrm{C}$.

Formalin-fixed, paraffin-embedded tissues (from a patient who underwent heart transplantation $12 \mathrm{wk}$ after the onset of acute $\mathrm{KD}(6)$, from a patient who died $3 \mathrm{wk}$ after the onset of $\mathrm{KD}$, and from a non-KD patient) were extracted with octane and ethanol and then digested using a procedure described elsewhere $(2,11)$. Ten- $\mu$ mthick tissue sections were digested in $200-\mu \mathrm{L}$ volumes; 1- and 10- $\mu \mathrm{L}$ aliquots were each analyzed with four pairs of broad-range bacterial 16S rDNA PCR primers in independent reactions: $8 \mathrm{FPL}+806 \mathrm{R}, 515 \mathrm{FPL}+$ 806R, 515FPL + 13B (same as p13B in Ref. 2), and 91E (same as p93E in Ref. 2) + 13B (11). Forty PCR cycles with an annealing temperature of $60^{\circ} \mathrm{C}$ were used along with other conditions described elsewhere (11). In reactions involving primers 515FPL $+13 \mathrm{~B}$ and $91 \mathrm{E}+$ 13B, $50 \mu \mathrm{g} / \mathrm{mL}$ 8-methoxypsoralen (Sigma Chemical Co., St. Louis, MO) were included in the reaction mixes, and the latter were UV irradiated at $366 \mathrm{~nm}$ for $7 \min (12)$.

The patient samples tested for bacteria were taken from 12 independent $\mathrm{KD}$ patients.

\section{RESULTS}

Detection of human herpesviruses. None of 14 peripheral blood DNA obtained from acute KD patients within the first $10 \mathrm{~d}$ of illness and before gamma globulin therapy were positive for human herpesvirus DNA sequences (Fig. 1). All 14 samples produced an amplified fragment of the expected size by PCR using HLA primers, demonstrating that the DNA was of sufficient quality to be amplified. Samples were tested in duplicate for herpesvirus DNA.

Detection of human and animal parvoviruses. Peripheral blood DNA samples from all 14 acute $\mathrm{KD}$ patients were negative for parvovirus DNA sequences as determined by dot-blot hybridization. In addition, all 15 acute $\mathrm{KD}$ patient sera assayed in duplicate were also negative for parvovirus DNA (Fig. 2). The parvovirus assay can detect as little as $10 \mathrm{ng}$ of parvoviral DNA in serum (data not shown).

Detection of eubacterial DNA. Bacterial rDNA could not be detected by PCR assays after 25 cycles with broad range primers $91 \mathrm{E}+13 \mathrm{~B}$ in any of the following $\mathrm{KD}$ patient tissues: eight buffy-coat samples, the single synovial fluid sample, and one fresh-frozen myocardial tissue sample. Digests of these tissues generated a DNA product of the expected size with human HLA primers, indicating that they contain amplifiable DNA (data not shown).

Furthermore, bacterial rDNA could not be detected in any of the three following formalin-fixed, paraffinembedded tissue digests that contained amplifiable DNA: myocardium and coronary artery from the $\mathrm{KD}$ patient who underwent heart transplantation and myocardium from the $\mathrm{KD}$ patient who died at $3 \mathrm{wk}$ after the onset of illness. All samples were tested in duplicate on at least two occasions. With these latter amplification conditions, the sensitivity of the PCR assays using each of the four pairs of broad-range bacterial 16S rDNA primers was estimated using serial dilutions of $E$. coli cells that were digested along with sections of a formalin-fixed, paraffin-

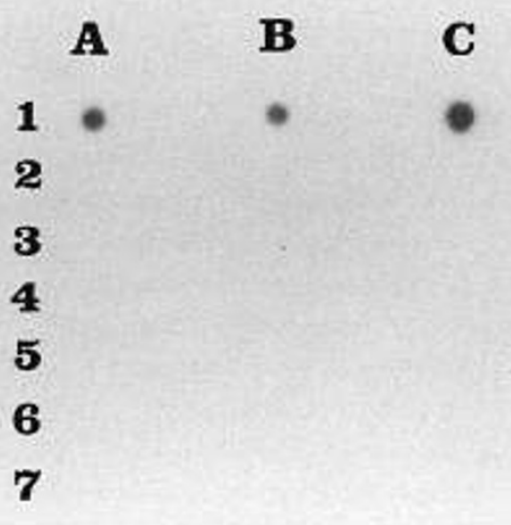

Figure 1. Dot-blot hybridization of amplified acute $\mathrm{KD}$ peripheral blood DNA using herpesvirus primers and generic herpesvirus probe. Positive controls include herpes simplex virus type 1 plasmid DNA, seen in dot B1, and DNA extracted from lymphocytes from a patient with CMV viremia, seen in $A 1$ and $C 1$. $A 3$ to $A 6, B 3$ to $B 7$, and $C 2$ to $\mathrm{C} 6$ are $\mathrm{KD}$ patient samples, and the other dots are negative controls. 


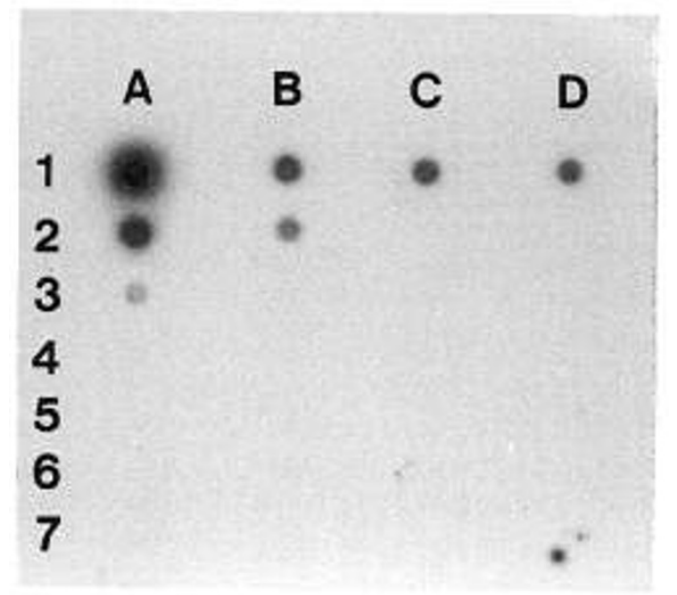

Figure 2. Dot-blot hybridization of acute $\mathrm{KD}$ sera with degenerate parvovirus probe. A1 to A6 are 10-fold dilutions of adeno-associated virus plasmid DNA in control negative serum, starting at $1 \mu \mathrm{g}$ in A1. The limit of detection of parvovirus DNA in this assay is therefore 10 ng. B1 and B2 are human parvovirus B19 and adeno-associated virus plasmid DNA in control negative serum, respectively. $\mathrm{C} 1$ is bovine parvovirus plasmid DNA, and D1 is minute virus of mice plasmid DNA, both in control negative sera. The patient samples are B3-B7, C2-C6, and D2-D6. The remaining dots are negative controls.

embedded negative control lymph node tissue. The sensitivity of these assays varied considerably, depending on the particular primer pair [8FPL $+806 \mathrm{R}$, approximately $10^{6}$ bacteria $\left(7 \times 10^{6} 16 \mathrm{~S}\right.$ rRNA gene copies $) ; 515 \mathrm{FPL}+$ $806 \mathrm{R}$, approximately $4 \times 10^{3}$ bacteria $\left(1 \times 10^{4} 16 \mathrm{~S}\right.$ rRNA gene copies); $515 \mathrm{FPL}+13 \mathrm{~B}$, approximately 40 bacteria (100 16S rRNA gene copies); and 91E + 13B, approximately 10 bacteria (70 16S rRNA gene copies)].

\section{DISCUSSION}

Because the clinical and epidemiologic features of $\mathrm{KD}$ so strongly support an infectious cause, intense investigation has focused on identifying an infectious agent of the illness. Conventional methods such as culture of patient samples and serologic studies for known infectious agents have yielded negative results. To date, few rigorous or extensive efforts have been made to apply molecular biologic techniques to the study of $\mathrm{KD}$ etiology.

Based on the propensity of herpesviruses, parvoviruses, and certain bacteria to cause clinical syndromes in children with some features similar to those of $\mathrm{KD}$, we have sought evidence of these groups of agents in $\mathrm{KD}$ patient samples using highly sensitive molecular techniques. Our approach was based on PCR or dot-blot hybridization detection methods for DNA sequences highly conserved among each of these groups of microorganisms. The results of these studies were negative and suggest one of three possibilities: 1) herpesviruses, parvoviruses, and bacteria are not involved in the etiology of $\mathrm{KD} ; 2$ ) one of these groups of agents is involved in the initiation of this disease process but is no longer present at the time of sample procurement; or 3) one of these groups of agents participates in the ongoing tissue pathol- ogy but is either present in numbers below the limit of our detection or is a genetic variant that does not share enough sequence similarity to allow for detection using our PCR primers or oligonucleotide probes. In the context of this study, the possibility of genetic variation might be more relevant to herpesvirus and parvovirus detection than to bacterial detection. Because highly conserved sequences were targeted for amplification and hybridization, the sensitivity of the assays may not be as high as could be obtained for individual viruses using specific sequences not conserved among the viral families. However, our goal was to detect highly conserved sequences to enhance the identification of a new member of these viral families.

Small subunit rRNA sequence analysis forms the basis for the determination of evolutionary relationships among all known cellular organisms (13). PCR amplification of bacterial 16S rDNA sequences directly from infected tissues is a powerful experimental approach that has led to the identification of the etiologic agents of several diseases long suspected to have a bacterial cause, but in which bacteria could not be readily cultured by conventional methodology (3). The bacterial etiologic agents of bacillary angiomatosis (2) and Whipple's disease (14) have been identified by amplification of 16S rRNA genes.

Using PCR primers that amplify highly conserved bacterial chromosomal 16S rDNA gene sequences and mediate amplification of various portions of this gene, we did not detect bacterial DNA in a variety of $\mathrm{KD}$ patient samples. These consisted of eight peripheral blood buffycoat samples from acute KD patients, a synovial fluid sample from an acute KD patient, frozen autopsy myocardial tissue from a child who died on d 18 of $\mathrm{KD}$, formalin-fixed, paraffin-embedded myocardial and coronary artery tissue from a patient who underwent cardiac transplant $12 \mathrm{wk}$ after onset of $\mathrm{KD}$, and myocardial tissue from a child who died $3 \mathrm{wk}$ after the onset of $\mathrm{KD}$. These results argue against a direct etiologic role for a bacterial agent in KD. Our level of sensitivity of bacterial detection varied with the use of different primer pairs from approximately $10^{1}$ to $10^{6}$ bacteria per digested sample. In addition, the possibility still exists that $\mathrm{KD}$ is an illness mediated by systemic release of a bacterial toxin or other cellular product, presumably elaborated by bacteria that are colonizing a mucosal site. This has been suggested by Abe et al. (4), who believe that a bacterial superantigen plays a role in the pathogenesis of the illness.

The approach that we have used to detect highly conserved genomic sequences within groups of microorganisms may be adapted to the study of other groups of microorganisms and may yet prove useful in the identification of an etiologic agent of KD. Such an approach may also prove useful in studies of other illnesses of unknown etiology that are suspected to be microbial in origin (3).

Acknowledgment. The authors thank Kathleen Corydon and Bill Kabat for their assistance; Drs. Richard Ringel 
and Wolfgang Mergner for providing formalin-fixed, paraffin-embedded blocks; and Dr. Donald Regula (Stanford University) for his assistance with histologic examination and initial processing of these blocks.

\section{REFERENCES}

1. Rowley AH, Gonzalez-Crussi F, Shulman ST 1991 Kawasaki syndrome. Curr Probl Pediatr 21:387-405

2. Relman DA, Loutit JS, Schmidt TM, Falkow S, Tompkins LS 1990 The agent of bacillary angiomatosis. N Engl J Med 323:1573-1580

3. Relman DA 1993 The identification of uncultured microbial pathogens. J Infect Dis 168:1-8

4. Abe J, Kotzin BL, Jujo K, Melish ME, Glode MP, Kohsaka T, Leung DY 1992 Selective expansion of $T$ cells expressing $T$-cell receptor variable regions Vbeta2 and Vbeta 8 in Kawasaki disease. Proc Natl Acad Sci 89:4066-4070

5. Terai M, Kohno Y, Namba M, Umemiya T, Niwa K, Nakajima H, Mikata A 1990 Class II histocompatibility antigen expression on coronary arterial endothelium in a patient with Kawasaki disease. Human Pathol 21:231-234

6. Travaline JM, Hamilton SM, Ringel RE, Laschinger JC, Ziskind AA 1991 Cardiac transplantation for giant coronary artery aneurysms complicating Kawasaki disease. Am J Cardiol 68:560-561
7. Wolinsky SM, Andersson JP, Rowley AH 1990 Detection of a highly conserved region of herpes viridae DNA by in vitro enzymatic amplification: application to the detection of a new human herpesvirus. In: Lopez C, Whitley R, eds. Immunobiology and Prophylaxis of Human Herpes Virus Infections. Plenum Press, New York, pp 219-229

8. Saiki RK, Bugawan TL, Horn GT, Mullis KB, Erlich HA 1986 Analysis of enzymatically amplified beta-globin and HLA DQ alpha DNA with allelespecific oligonucleotide probes. Nature 324:163-166

9. Arella M, Garzon S, Bergeron J, Tijssen P 1990 Physiochemical properties, production, and purification of parvoviruses. CRC Handbook of Parvoviruses, Vol 1. CRC Press, Boca Raton, FL, pp 11-30

10. Chomczynski $P$, Sacchi $N 1987$ Single-step method of RNA isolation by acid guanidium thiocyanate-phenol-chloroform extraction. Anal Biochem 162:156159

11. Relman DA 1993 Universal bacterial 16S rDNA amplification and sequencing. In: Persing DH, ed. Diagnostic Molecular Microbiology: Principles and Applications. American Society of Microbiology, Washington, DC, pp 489-495

12. Meier A, Persing DH, Finken M, Bottger EC 1993 Elimination of contaminating DNA within DNA chain reaction reagents: implications for a general approach to detection of uncultured pathogens. J Clin Microbiol 31:646-652

13. Woese CR 1987 Bacterial evolution. Microbiol Rev 51:221-271

14. Relman DA, Schmidt TM, MacDermott RP, Falkow S 1992 Identification of the uncultured bacillus of Whipple's disease. N Engl J Med 327:293-301

\section{ANNOUNCEMENT Search for European Chief Editor Pediatric Research}

After five years of service, the European Editorial Board of Pediatric Research will complete its term on December 31, 1995. The Board of Trustees of the International Pediatric Research Foundation has established a Search Committee to review the credentials of qualified candidates for a new European Chief Editor and to make recommendations to the Board, which has the responsibility for final selection.

The Search Committee seeks candidates or recommendations for individuals who might serve as European Chief Editor. The European Chief Editor must be a member of the European Society for Pediatric Research. Interested individuals should submit six copies of their curriculum vitae and those of at least four individuals in their locale to serve as Associate Editors. In addition, the application should include suggestions for further improving the quality of Pediatric Research and its growth as a unique biomedical publication. The office carries a budget for supporting staff and an honorarium. Additional information regarding the operation of the European Office can be obtained from the current European Editor, Pieter J. J. Sauer, M.D., Sophia Children's Hospital, Dr. Molewaterplein 60, 3015 GJ Rotterdam, The Netherlands.

The Search Commitee will interview selected candidates immediately before the annual meeting of the Board of Trustees in September 1995. Applications should be sent before February 1, 1995, to: Gunnar Sedin, M.D., Chairman, Search Committee, Department of Pediatrics, Uppsala University Children's Hospital, S-751 85 Uppsala, Sweden. 